\title{
PERMOHONAN IJIN POLIGAMI TIDAK SESUAI DENGAN ALASAN DAN SYARAT-SYARAT HUKUM POSITIF INDONESIA
}

\author{
Eti Mul Erowati \\ Dosen Fakultas Hukum Universitas Wijayakusuma Purwokertto \\ Jl. Beji Karangsalam Purwokerto. 53152 \\ Email:Pujaestryana25@gmail.com
}

\begin{abstract}
ABSTRAK
Hakim dalam mengadili permohonan ijin poligami yang dasar alasan-alasan dan syaratsyaratnya tidak sesuai hukum positif saat ini yakni pasal 4 ayat 2 dan pasal 5 ayat 1 huruf (a) dan ayat 2 Undang-undang Nomor 1 tahun 1974 tentang Perkawinan tetap dikabulkan dengan pertimbangan kemaslahatan dan keadilan, dan hakim dibenarkan melakukan ijtihad hukum dengan menyimpangi norma hukum yang ada (Istihsan), demi tercapainya kepastian dan keadilan hukum berdasarkan prinsip the judge made of law dan living law, guna memberikan kepastian hukum, manfaat hukum serta keadilan hukum bagi keluarga besar poligami (Rech Ide) untuk menolak akibat bahaya
\end{abstract}

( Madlorot), yang lebih besar dikemudian hari.

Kata Kunci: poligami, perkawinan.

\section{A. PENDAHULUAN}

Sebelum syari'at Islam lahir, kaum wanita berada pada posisi yang sangat lemah, karena nyaris tidak memiliki peran apa-apa dalam percaturan kehidupan dalam segala hal. Keberadaanya hanya menjadi sasaran pelampiasan nafsu sahwat kaum pria dengan carayangsewenang-wenang, dikalaituseorang pria kapan saja dapat memperistri sejumlah wanita melalui perkawinan matrelinial, Uksorilokal, (sangat menggandrungi wanita), perkawinannya bersifat poliandri dan poligami. ${ }^{1}$ tanpa batas, namun tidak diurusi segala keperluan kehidupannya, istri-istri yang dimilikinya dapat dilepaskan kapan saja tanpa adanya hukum dan undangundang yang melindunginya. ${ }^{2}$ kaum wanita tidak pernah memperoleh hak untuk dapat melepaskan diri dari situasi dan kondisi yang

${ }^{1}$ Leila Ahmed.(2000). Women and Gender In Islam, Yale University Press, New Haven \& London, 1992, diterjemahkan oleh Nasrulloh dengan judul Wanita dan Gender Dalam Islam, Jakarta: PT. Lentera Basritama, hlm.45.

${ }^{2}$ Saiful Islam Mubarok.(2003). Poligami yang didambakan wanita, Bandung: Sya'amil cipta media, hlm.1. tidak menyenangkan itu. ${ }^{3}$ Anwar Harjono menyebut perkawinan poligami dikala itu adalah satu hal yang umum terdapat dikalangan mereka dan tidak terbatas ketika itu. $^{4} \quad$ Situasi yang demikian oleh Hamim Ilyas..$^{5}$ disebut sebagai keadaan yang ironi.

Ketika syari'at Islam lahir dengan ajarannya yang mendasarkan pada wahyu Alloh SWT berupa Al-qur'an dan Hadishadis Nabi, membawa perubahan peradaban umat manusia yang sangat besar termasuk dibidang perkawinan poligami. Turunnya syari'at poligami (Double mirage) melalui surat A-nisa' ayat 3 merupakan salah satu bukti adanya pembaharuan peradaban hukum poligami yang dahulu biasa dipraktekkan secara tidak manusiawi. Syari'at Islam mengenai poligami bertujuan melindungi diri, harkat, martabat serta kemuliaan kaum wanita dari perlakuan semena-mena kaum

\footnotetext{
${ }^{3}$ Ibid., hlm.2.

${ }^{4}$ Anwar Harjono.(2004). Hukum Islam Keluasan dan Keadilannya, Jakarta: PT. Bulan Bintang, hlm.40.

${ }^{5}$ Hamim Ilyas.(2009). Perempuan Tertindas, Yogyakarta, hlm.2.
} 
laki-laki sebagaimana yang terjadi dalam peradaban sebelum Islam. ${ }^{6}$ Bukti itu dapat kita baca dalam kisah seorang laki-laki dari bangsa Tsaqif bernama Ghailan bin Salamah yang ketika masuk Islam mimiliki sepuluh istri, maka Rosululloh SAW menyuruhnya untuk memilih empat orang istri saja dan menceraikan enam orang istri lainnya, demikian pula Haris bin Qois yang mempunyai delapan istri, maka Rosululloh memerintahkan agar memilih empat istri saja dan menceraikan empat lainnya. ${ }^{7}$

Di masa kerajaan-kerajaan Jawapun (locaal wisdom) soal perkawinan poligami bukan hal yang asing dan tabu, sejarah telah mencatat bahwa dalam kehidupan raja-raja jawa tempo dulu sebagaimana kerajaan hindu budha, maupun kerajaan Mataram Islam pola perkawinan poligami telah menghiasi perjalanan kehidupan para raja-raja jawa. Dalam ekspresi budaya katuranggan misalnya dengan data-datanya yang empirik membuktikan bahwa kehidupan yang dijalani para raja - raja Jawa atau pangeran didasarkan pada penglihatan (candra) atas perempuan yang akan dijadikan istri poligaminya dengan melihat atau mencandra perempuan atas kondisi fisik wanita yang dipilihnya kaitannya dengan potensi seksual yang dimiliki perempuan tersebut. ${ }^{8}$ karena disamping diyakini sebagai wujud pengamalan sebagian ajaran agama dibidang muamalah yang dianutnya juga sebagai sebuah kebutuhan gaya kehidupan dimasanya.

Persoalan poligami menjadi sesuatu yang layak untuk dikaji karena di Negara Republik Indonesia yang mayoritas penduduknya beragama Islam, dimana poligami diatur dalam undang-undang yakni pasal 3 ayat 2 Undang-undang nomor 1 tahun 1974 tentang Perkawinan , namun dikatakan dalam pasal 4 ayat 2 dan pasal 5 ayat 1 huruf (a) dan ayat 2 Undang-undang Nomor 1 Tahun 1974 tentang

\footnotetext{
${ }^{6}$ Saiful Islam Mubarok, Ohlm.cit, hlm.4.

${ }^{7}$ Islah Gusmian.(2007). Mengapa Nabi Muhammad berpoligami, Yogyakarta: Pustaka Marwa cet.1, hlm.177.

${ }^{8}$ Zaki Mubarok.(2012). Analisis feminism tentang fikih perempuan dalam serat chentini, Justisia , Jurnal Pemikiran Keagamaan dan Kebudayaan edisi 39 Th.XXIII, Semarang, hlm.100.
}

Perkawinan mempersulit poligami, akibatnya banyak masyarakat dalam melakukan poligami dengan cara melawan hukum seperti poligami tanpa ijin pengadilan sehingga tidak tercatat, poligami sirri dan lain-lain, fakta itu mulai nampak tatkala kasus poligami sirri Murdiono -Machica Mochtar yang melahirkan anak Muhammad Iqbal muncul ke permukaan, belum lagi kasus-kasus poligami sirri yang terjadi di tingkat lokal yang begitu menggurita, dimana dampak sosial dari peristiwa itu demikian luas karena status hukum keperdataan menyangkut status perkawinannya, status keperdataan dan hak-hak keperdataan anaknya tiada ujung ahir hingga saat ini dan selalu mengundang debateble.

Sebagaimana ditentukan pasal 4 ayat 2 dan pasal 5 ayat 1 huruf (a) dan pasal 2 undang-undang nomor 1 tahun 1974 tentang perkawinan bahwa ijin beristri lebih dari seseorang (poligami) hanya dapat diberikan apabila memenuhi alasan-alasan dan syaratsyarat sebagai berikut yaitu:

1. Istri tidak dapat menjalankan kewajibannya sebagai istri;

2. Istri mendapat cacat badan atau penyakit yang tidak dapat disembuhkan;

3. Istri tidak dapat melahirkan keturunan.

Sedang syarat - syarat ijin poligami pasal 5 ayat 1 dan ayat 2 adalah :

1. Adanya persetujuan tertulis dari istri/istriistri.

2. Adanya kepastian bahwa suami mampu menjamin keperluan-keperluan hidup istriistri dan anak-anak mereka.

3. Adanya jaminan bahwa suami akan berlaku adil terhadap istri-istri dan anak-anak mereka.

Ayat 2 Persetujuan yang dimaksud ayat1 huruf (a) tidak diperlukan bagi suami apabila istri tidak mungkin dimintai persetujuannya dan tidak dapat menjadi pihak dalam perjanjian atau apabila tidak ada kabar dari istrinya sekurang-kurangnya 2 tahun, 
atau arena sebab-sebab lainnya yang perlu mendapat penilaian dari hakim Pengadilan. ${ }^{9}$

Dengan Hakim mengabulkan permohonan ijin poligami yang dasar permohonannya tidak berpijak pada undang-undang, dalam hal ini pasal 4 ayat 2 dan pasal 5 ayat 1 khususnya huruf (a) dan ayat 2, terdapat perbedaan yang jelas antara hukum yang seharusnya (Das Sollen), yaitu alasan-alasan dan syarat-syarat ijin poligami menurut pasal 4 ayat 2 dan pasal 5 ayat 1 huruf (a) dan ayat 2 undang-undang nomor 1 tahun 1974 tentang perkawinan, dengan hukum yang senyatanya (Das Sein) yaitu putusan Hakim Pengadilan Agama yang mengabulkan permohonan ijin poligami dengan pertimbangan diluar norma hukum pasal 4 ayat 2 dan pasal 5 ayat 1 huruf (a) dan ayat 2 undang-undang nomor 1 tahun 1974 tentang perkawinan tersebut. Oleh karena itu agar jelas bagaimana seharusnya ijin poligami di Indonesia dalam pandangan masyarakat pelaku poligami dan Hakimhakim Peradilan Agama di Indonesia antara hukum yang tertulis ( local wisdom), dengan hukum yang hidup di masyarakat (living law).

Berangkat dari kasus-kasus permohonan ijin poligami yang terjadi di pengadilan Agama, banyak ditemukan putusan-putusan mengenai ijin poligami yang meskipun alasanalasan dan syarat-syarat permohonanya tidak sesuai dengan hukum positif saat ini, namun Pengadilan Agama tetap mengabulkan permohonan ijin poligami tersebut dengan pertimbangan kemaslahatan, kemanusiaan serta keadilan.

Bertitik tolak dari uraian di atas, dirumuskan maka permasalahan yang timbul adalah sebagai berikut :

"Mengapa ijin poligami di Pengadilan Agama tidak sesuai dengan hukum positif saat ini?"

\section{B. PEMBAHASAN}

${ }^{9}$ Mahkamah Agung RI.(2014). Himpunan Peraturan Perundang-undangan dilingkungan Peradilan Agama, Jakarta: Dirjend. Badilag, hlm.339.
Friedman, ${ }^{10}$ mengemukakan bahwa hukum ditaati atau tidak, berjalan dengan baik atau tidak sangat bergantung pada tiga hal yakni substansi hukum, struktur hukum dan budaya hukum. Tentang substansi hukum poligami, norma hukum yang ada saat ini sebagaimana yang diatur pada pasal 3 ayat 2, pasal 4 dan pasal 5 Undang-undang Nomor 1 tahun 1974 telah sesuai atau selaras dengan nilai-nilai hukum Pancasila dan sejalan dengan nilai-nilai poligami hukum Islam. Sebab diakui atau tidak Islamlah pembaharu hukum poligami di dunia yang dahulu menurut catatan sejarah poligami dilakukan sesuai selera masyarakat dikala itu, karena selera sampai-sampai muncul istilah isteri selir. ${ }^{11}$ Kemudian dari segi Struktur hukum, apakah selama ini Hakim Pengadilan Agama yang mengadili kasus-kasus permohonan ijin poligami hanya berpaku pada normanorma hukum yang ada ataukah sebaliknya sang hakim telah bertindak responsif maupun progresif, kalau demikian halnya mengapa di masyarakat masih menjamur poligami secara melawan undang-undang karena tanpa memohon ijin poligami terlebih dahulu ke Pengadilan sehingga poligami sirri yang ditempuhnya, bahkan saking mendesaknya keinginan untuk berpoligami sementara mengurus ijin ke Pengadilan terbentur oleh aturan undang-undang poligami yang sulit, akibatnya dihamili terlebih dahulu calon istri poligaminya itu baru kemudian setelah hamil diajukan permohonan poligami ke Pengadilan. Kemudian dari sisi budaya hukum, mengapa masyarakat dewasa ini banyak berpoligami secara sirri bahkan berpoligami dengan cara berzinah terlebih dahulu, adakah perubahan mendasar pada prilaku masyarakat seperti itu akibat dari hukum poligami yang sulit di Indonesia?

Budaya hukum (legal cultur) dalam teori Friedman didefiniisikan sebagai "system

${ }^{10}$ Lawrence Meier Friedman.(1998). American Law : an Introductions, secondedition, New York: W.W. Norton \& Company, hlm. 20.

${ }^{11}$ Zaki Mubarok.(2012). Analisis Feminisme tentang fikih perempuan dalam serat Chentini, Journal Pemikiran Keagamaan Dan Kebudayaan, edisi 39,th. XXIII, Semarang, hlm.100. 
their benefit, values, ideas and expectations". Yakni sikap manusia terhadap hukum dan sistem hukum, kepercayaan, nilai, pemikiran, serta harapannya. ${ }^{12}$ Smith dan blumberg sebagaimana yang dikutip oleh Jaenal Aripin, ${ }^{13}$ juga mengemukakan bahwa yang dimaksud budaya hukum (legal cultur), adalah segala hal yang menyangkut cara berpikir dan bertindak para penegak hukum, yakni hakim di pengadilan dan sikap masyarakat terhadap hukum. Kalau term Friedman dan Smit serta Blumberg diatas kita kaitkan dengan prilaku masyarakat pelaku poligami dengan keberanian Hakim Pengadilan Agama membuat putusan poligami yang alasannya tidak sesuai hukum positif saat ini namun tetapp dikabulkan, maka timbul pertanyaan mengapa norma hukum mengenai alasanalasan dan syarat-syarat ijin poligami telah banyak disimpangi oleh Hakim ketika mengadili perkara ijin poligami, terdapat pertimbangan apa sehingga Hakim dalam mengambil putusan perkara poligami mengabaikan norma tentang alasan dan syarat poligami?

Sebagai bangsa yang berfalsafah dan ber idiologikan Pancasila mengenal adanya keadilan sosial. Menurut Fadil Sumadi. ${ }^{14}$ Keadilan sosial merupakan tampilan lain dari konsep keadilan pada umumnya, dimana yang dimaksud dengan keadilan sosial atau keadilan Pancasila itu menurut Soetandyo. ${ }^{15}$ adalah memberikan hak secara merata bagi setiap penduduk bangsa tanpa pembedaan dan pengecualian, tanpa diskriminasi. Keadilan sosial sendiri sesungguhnya refleksi dari nilai-nilai tujuan negara yakni melindungi segenap bangsa Indonesia dan seluruh tumpah darah berdasarkan nilai-nilai Ketuhanan, kemanusiaan, nilai persatuan dan

\footnotetext{
${ }^{12}$ Jaenal Aripin, Loc.Cit.

${ }^{13}$ Ibid., hlm. 119-120.

${ }^{14}$ Ahmad Fadlil Sumadi.(2012). Hukum Dan Keadilan Sosial, Materi Perkuliahan Program Doktor Ilmu Hukum Universitas Islam Sultan Agung, Jakarta: Tanpa Penerbit, hlm.5.

${ }^{15}$ Soetandyo Wignyo Soebroto.(2011). Hukum, keadilan dan masyarakat, Materi Perkuliahan umum Program Magister Ilmu Hukum Universitas Slamet Riyadi, Surakarta, hlm.4.
}

permusyawaratan, dalam kontek undangundang artinya setiap hukum yang dibuat harus diarahkan untuk terwujudnya keadilan sosial agar masyarakat makmur,sejahtera baik lahir maupun batin, karena itu dalam hubungannya dengan hukum poligami seharusnya adalah hukum poligami yang berkeadilan sosial.

Adanya teori Kemaslahatan dan teori Istihsan yang dikemukakan oleh Imam AlGhozali, sesungguhnya bertitik tolak dari tujuan dibuatnya perundang-undangan ( Maqosid As-syar'iyyah) didalam Islam, dimana tujuan dibuatnya undang-undang adalah untuk memelihara Agama, jiwa, akal, keturunan dan harta milik demi kebahagiaan umat manusia dunia akhirat. Term dari kemaslahatan adalah sesuatu yang mendatangkan kebaikan, faedah, atau meraih manfaat untuk menghindarkan kemadlorotan (bahaya). ${ }^{16}$ Kalau selama ini anggapan masyarakat terhadap hukum poligami di Indonesia sulit, rumit, berat, dan berbelitbelit untuk meraihnya, maka jalan pintas yang mereka tempuh dalam berpoligami adalah poligami secara sirri tujuannya untuk menghindari kesulitan, karena undangundang perkawinan sendiri selama ini menutup rapat-rapat pintu poligami sehingga poligami di Indonesia antara ada dan tidak ada. Maka tindakan Hakim Pengadilan Agama yang memberikan jalan keluar dari kesulitan kepada masyarakat pemoohon poligami dengan menerapkan teori Istihsan dan teori kemaslahatan, merupakan langkah bijak dari manifestasi bahwa hakim adalah pembuat undang-undang.

Banyak didapatkan putusan-putusan Pengadilan Agama dalam perkara ijin poligami alasan-alasan dan syarat-syarat yang dijadikan dasar mengajukan permohoan tidak mendasarkan pada norma hukum pasal 4 ayat 2 dan norma hukum pasal 5 ayat 1 huruf a dan ayat 2 Undang-undang Nomor 1 tahun 1974 tentang Perkawinan. Misalnya

${ }^{16}$ Abu Hamid Muhamad Ibn Muhammad Al-Ghozali, Al-Mustasyfa min Jami'il ushul, juz I, Al-kutub aal-ilmiyyah, Beirut, tt, hlm.286.

364 Eti Mul Erowati | Permohonan Ijin Poligami Tidak.... 
adalah putusan Pengadilan Agama perkara ijin poligami nomor :703/Pdt.G/2014/PA.Bla. yang diputus Majelis Hakim Pengadilan Agama Blora pada tanggal 28 Agustus 2014, kasus posisinya $A S$ seorang Pegawai Negeri sipil yang menjabat Kepala Urusan Sosial di Kelurahan Tutup Kecamatan Tunjungan Kabupaten Blora telah berpacaran dengan $\mathrm{NH}$ gadis desa, akibat hubungan mesranya $N H$ hamil, maka dalam posisi seperti itu ayah kandung $\mathrm{NH}$ bernama Kusman menuntut agar $A S$ menikahi anaknya yang telah dihamilinya, karena $A S$ punya istri dengan 2 orang anak, maka perkawinan yang dilakukan harus secara poligami dengan dalih agar janin yang dikandung $\mathrm{NH}$ mempunyai status hukum yang jelas dan status perkawinanya juga jelas, karena ada norma yang mengatur dalam pasal 53 Kompilasi Hukum Islam yang menyatakan wanita hamil luar nikah dapat dinikahkan dengan laki-laki yang menghamilinya. ${ }^{17}$ Karena alasan keterpaksaan, Maka $A S$ kemudian mengajukan permohonan ijin poligami ke Pengadilan Agama Blora dengan alasan (1). istri pertama Pemohon dalam keadaan sudah tua, padahal riil dalam permohonan Termohon baru berusia 41 tahun dan dari perkawinan yang pertama pasangan tersebut telah dikaruniai anak 2 orang, alasan (2).Karena calon istri madunya telah hamil bahkan hingga melahirkan anak yang diberi nama FN. Dalam putusannya Majelis Hakim mengabulkan permohonan Pemohon dengan amar memberikan ijin kepada Pemohon $A S$ untuk menikah secara poligami dengan $N H$. Kalau kita berpijak pada sistem hukum camon law bahwa hukum adalah aturan yang tertulis yang dikodifikasikan, secara normatif berdasarkan pasal 4 ayat 2 Undang-undang Nomor 1 tahun 1974 tentang Perkawinan hakim mengabulkan ijin poligami Pemohon jelas tidak tepat, karena ijin poligami hanya terbatas atas tiga alasan di atas, sedangkan dasar yang dijadikan alasan Pemohon mengajukan permohonan poligaminya tidak memenuhi unsur-unsur pasal 4 ayat 2 Undang-undang Nomor 1 tahun 1974 tentang

\footnotetext{
${ }^{17}$ Mahkamah Agung RI, Ohlm.cit, hlm.1030.
}

perkawinan sebagai syarat alternatif, terlebih lagi jika diperhatikan fatwa Majelis Ulama Indoneesia nomor 11 tahun 2012 tentang status anak luar nikah, jelas bahwa anak lahir luar perkawinan hanya bernasab kepada ibunya. Karena itu perlu dikaji pertimbangan hukum apa dan teori hukum apa yang dipakai Hakim dalam hal ini Pengadilan Agama Blora, sehingga mengabulkan permohonan ijin poligami Pemohon, didapatkan fakta bahwa pertimbangan hukum Hakim dalam memutus permohonan ijin poligami adalah atas pertimbangan Kemaslahatan (kebaikan bersama) dalam hal ini keluarga besar pelaku poligami, berdasarkan kaidah ushul fiqih yang menyatakan : Kemaslahatan umum harus didahulukan daripada kemaslahatan khusus, kemudian kaidah ushul fiqih yang menyatakan : Menolak kerusakan harus didahulukan dari pada menarik kebaikan.

Bahwa mengabulkan permohonan ijin poligami demi kepentingan umum yakni demi kepentingan manfaat hukum pemohon poligami, istri pertama poligami, calon istri kedua poligami yang telah hamil demi kepastian hukum, anak-anak keturunan keluarga poligami agar mendapatkan keadilan hukum dari ayahnya tujuannya adalah mendatangkan kebaikan dan jika permohonan poligami dengan alasan tersebut ditolak Pengadilan, maka hanya akan mendatangkan kemudlorotan besar bagi keluarga besar pemohon poligami, akibat tidak diperolehnya kepastian dan keadilan hukum.

\section{KESIMPULAN}

Berdasarkan uraian tersebut di atas, Hakim dalam mengadili permohonan ijin poligami yang dasar alasan-alasan dan syaratsyaratnya tidak sesuai hukum positif saat ini yakni pasal 4 ayat 2 dan pasal 5 ayat 1 huruf (a) dan ayat 2 Undang-undang Nomor 1 tahun 1974 tentang Perkawinan tetap dikabulkan dengan pertimbangan kemaslahatan dan keadilan, dan hakim dibenarkan melakukan ijtihad hukum dengan menyimpangi norma hukum yang ada (Istihsan) dalam hal ini pasal 4 ayat 2 dan pasal 5 ayat 1 huruf (a) 
dan ayat 2 Undang-undang Nomor 1 tahun 1974 tentang Perkawinan demi tercapainya kepastian dan keadilan hukum berdasarkan prinsip the judge made of law artinya Hakim adalah pembentuk undang-undang, dan living law / hukum yang hidup di masyarakat seperti fikih klasik sebagai locaal wisdom, karena pada dasarnya undang-undang Kekuasaan Kehakiman sendiri pada pasal 14 ayat (1) undang-undang nomor 4 tahun 2004 sebagaimana diubah dan ditambah melalui undang-undang nomor 48 tahun 2009, telah mengatur bahwa Hakim tidak boleh menolak mengadili perkara dengan alasan hukum tidak ada atau kurang jelas, melainkan wajib mengadilinya, lalu dihubungkan dengan pasal 28 ayat (1) undang-undang tersebut yang berbunyi : Hakim wajib menggali,mengikuti, dan memahami nilai-nilai hukum dan rasa keadilan dalam masyarakat" artinya hukum yang hidup dan berkembang di masyarakat (living law), guna memberikan kepastian hukum, manfaat hukum serta keadilan hukum bagi keluarga besar poligami (Rech Ide) untuk menolak akibat bahaya ( Madlorot), yang lebih besar dikemudian hari.

\section{DAFTAR PUSTAKA}

Anwar Harjono.(2004). Hukum Islam Keluasan dan Keadilannya, Jakarta: PT.Bulan Bintang.

Ahmad Fadlil Sumadi.(2012). Hukum Dan Keadilan Sosial, Materi Perkuliahan Program Doktor Ilmu Hukum Universitas Islam Sultan Agung, Jakarta.Abu Hamid Muhamad Ibn Muhammad Al-Ghozali, AlMustasyfa min Jami'il ushul, juz I, Al-kutub aal-ilmiyyah, Beirut.

$\begin{array}{crr}\text { Hamim } & \text { Ilyas.(2009). } & \text { Perempuan } \\ \text { Tertindas,Cetakan } & \text { ke } \text { empat, } \\ \text { Yogyakarta. } & & \end{array}$

Islah Gusmian.(2007). Mengapa Nabi Muhammad berpoligami, Yogyakarta: Pustaka Marwa cet.1.
In Islam,Yale University Press, New Haven \& London, 1992, diterjemahkan oleh Nasrulloh dengan judul Wanita dan Gender Dalam Islam, Jakarta: PT. Lentera Basritama.

Lawrence Meier Friedman.(1998). American Law : an Introductions, secondedition, New York, W.W. Norton \& Company. Mahkamah Agung RI.(2014). Himpunan Peraturan Perundang-undangan dilingkungan Peradilan Agama, Dirjend,Jakarta: Badilag.

Saiful Islam Mubarok.(2003). Poligami yang didambakan wanita, Bandung: Sya'amil cipta media.

Soetandyo Wignyo Soebroto.(2011). Hukum, keadilan dan masyarakat, Materi Perkuliahan umum Program Magister Ilmu Hukum Universitas Slamet Riyadi, Surakarta.

Zaki Mubarok.(2012). Analisis Feminisme tentang fikih perempuan dalam serat Chentini,Journal pemikiran keagamaan dan kebudayaan, edisi 39, Semarang.

Leila Ahmed.(2000). Women and Gender 